\title{
FACTORS ASSOCIATED WITH ADHERENCE TO TAKING IRON TABLET AMONG PREGNANT WOMEN IN LEBAK, BANTEN
}

\author{
Ninik Wahyuni'1), Aquartuti Tri Darmayanti²) \\ 1)School of Health Polytechnics, Banten \\ 2)Masters Program in Public Health, Universitas Sebelas Maret
}

\begin{abstract}
Background: Pregnant women are at high risk of iron deficiency anemia due to increased nutrient requirement during pregnancy. Iron deficiency anemia can make individuals feel tired and exhausted. Severe anemia can also lead to complications in pregnancy. For instance, it can weaken the mother's immune system and make infections more likely. It also increases the risk of low birth weight. Adherence to taking iron tabletis a key to prevention and control of iron deficiency anemia. This study aimed to determine factors associated with iron tablet adherence in pregnant women.
\end{abstract}

Subjects and Method: This was a cross-sectional study, carried out at Puskesmas (Community Health Center), Mandala, Lebak, Banten, from July to October 2017. A sample of 185 pregnant women was selected by accidental sampling. The dependent variable was adherence to take iron tablet. The independent variables were maternal knowledge, attitude, and husband support. The data were collected by questionnaire and analyzed by a multiple logistic regression.

Results: Adherence to take iron tablet increased with good maternal knowledge $(\mathrm{OR}=5.61 ; 95 \% \mathrm{CI}=2.47$ to $12.77 ; \mathrm{p}<0.001)$, positive attitude $(\mathrm{OR}=5.58 ; 95 \%$ $\mathrm{CI}=2.68$ to $11.61 ; \mathrm{p}<0.001)$, and strong husband's support $(\mathrm{OR}=5.53 ; 95 \% \mathrm{CI}=$ 2.60 to $11.73 ; \mathrm{p}<0.001)$.

Conclusion: Adherence to take iron tablet increases with good maternal knowledge,positive attitude, and strong husband's support.

Keywords: adherence, iron tablet, maternal knowledge, attitude, husband support.

\section{Correspondence:}

Ninik Wahyuni. School of Health Polytechnics, Banten, Rangkasbitung, Banten. Email: ninikasih@gmail.com. Mobile: 081310626579 